\title{
From Headhunting to Head Taxes
}

\author{
Violence, Taxation and Colonial Governance on Seram, c. 1860-1920
}

\author{
Maarten Manse | ORCID: 0000-0001-5906-3135 \\ Leiden University, Leiden, The Netherlands \\ m.r.manse@law.leidenuniv.nl
}

\begin{abstract}
This article investigates Dutch colonial practices on the Moluccan island of Seram in the late nineteenth and early twentieth centuries. Seram's mountainous interior was the domain of ungoverned, peripatetic Alfurs who engaged in headhunting. For a long time, they were rendered untouched by colonialism and administered through coastal intermediaries. After 1900, renewed imperial-civilizational vigour demanded the direct incorporation and 'civilization' of Seram's stateless spaces. A series of expeditions subjected the Alfurs to registration, categorization, and taxation, which this article argues were seen as pivotal, moralizing tools of colonial social-engineering, used to inscribe subjected people into the state and instil compliant and 'productive' behaviour. However, rather than a replacement of indigenous orders with European modernity, colonization produced a hybrid fusion of colonial strategies of domination with indigenous cultural practices of state-evasion. This article demonstrates that colonial governance was a site of interaction, in which colonial developmentalism and modernity were actively negotiated and challenged.
\end{abstract}

\section{Keywords}

colonial governance - taxation - Seram - statelessness

Colonial statecraft is seen as intimately tied to processes of knowledge accumulation and data-gathering. Scholarship of the last decades has unveiled how practices and modalities of knowledge construction were integral to the establishment and expansion of modern colonial empires and their developmentalist ambitions (Noor 2020:17; Cohn 1996). 
This article reflects on such processes of colonial knowledge acquisition, expansion, development, and reform and aims to demonstrate that strategies of knowledge accumulation and intervention were rarely agreed upon, shifted over time, and were subject to constant challenges from within and beyond the state. It discusses the case of the Moluccan island of Seram, by examining the introduction of taxes, which I argue played a crucial role in colonial processes of expansion, subjection, and development. Seram provides an excellent case study for an in-depth analysis of colonial ambitions of social improvement and the ways these were compromised by a fusion of local agency and predicaments within the colonial state.

Whereas across Indonesia Dutch officials located various societal aspects to tie their systems of taxation and governance into, Seram was among the 'stateless spaces' considered devoid of economic resources or opportunities for state-building and taxation (Boulan-Smit 1998:43, 63; Tichelman 1925:69o2; Rutten 1920). Its mountainous and densely forested interior remained unmapped territory to Europeans as the domain of 'dissidents', 'pirates', and other 'state-escapers' (Boulan-Smit 2006:158). For long, Seram's interior and its original inhabitants, the Alfurs, or Alifuru, ${ }^{1}$ remained untouched by colonialism. The Alfurs were organized in heterogeneous, tribal societies and lived as seminomadic agriculturalists and hunters. They retained non-monotheistic religious beliefs based on ancestor-worshipping and were renowned and feared for practising headhunting. To colonial officials, they represented typical peripatetic, stateless tribal people unsuitable for modern governance, contrary to the 'civilized', state-bound subjects who lived along the coast of Seram and intermediated between the Dutch and the Alfurs.

Around 190o, however, the Dutch turn towards civilizational, 'ethical' colonialism demanded that the local government actively combated practices of headhunting and pursued the gradual improvement of the conditions under which the Alfurs lived. This related to general colonial paradigms of indigenous violence and instability, concerns about indigenous welfare, and the construction of 'successful' colonial subjects—all of which were fundamental to Dutch imperialist conquests as they fuelled the convictions that further legitimized

1 This was not an ethnic term but, rather, a geographical-cultural distinction (Manuhutu 1985:268-9). Dutch sources often speak of 'mountain dwellers' (bergbewoners) when addressing the Seramese Alfurs. 'Alfurs' became a collective term for non-monotheist Indonesian peoples in the interiors of eastern Indonesian islands, but in modern-day language the word is still in use to refer to the people of interior Seram and some other Moluccan islands (Bartels 1994:29; Sachse 1922:33). 
the colonial project of tutelage to generate the impression of legitimate and credible colonial rule (compare with Kloos 2014). By remaining outside the state, the Alfurs posed a threat to the continuation of the Dutch empire, and imposing taxes was a way to contain this threat.

Military intervention paved the way for more direct forms of Dutch governance on Seram and both necessitated and enabled more direct forms of taxation. Contemporary colonial ideology demanded local governments to fund themselves, using just and proper fiscal bureaucracy. Many officials believed that because taxes addressed fundamental facets of social organization (such as income, property, inheritance, and consumption patterns), they could be used as disciplinary tools and transformative devices to underpin colonial civilizational projects; facilitate greater welfare and participation of Seram in the global economy; shape obedient, categorized, industrious, and governable, taxpaying subjects; and materialize the colonial 'will to improve', which also rooted colonial self-legitimization ( $\mathrm{Li}$ 2007).

However, old patterns of headhunting, 'forest-dwelling', and statelessness were not easily eradicated. The modernizing ideals of Dutch ethical colonialism and its transformative forces were held in check by local realities of governance, the agency of local social organization, and various nodes of resistance and resilience. Instead, post-19oo Dutch colonialism ordered local governance to be carried out as much as possible through the 'emancipation' of local chieftains, thereby further empowering their position. Accordingly, the institutes, patterns, and structures underpinning these chiefs, which the colonial order formally aimed and claimed to replace or reform, started informing the performance of colonial rule.

Resultantly, colonial statecraft was not merely an exercise in data-collecting, mapping, and standardization, nor a unidirectional project of centralized administration, inscription, and documentation driven by an appetite to make society 'legible' and exert greater control for purposes of extraction and 'social improvement' (J. Scott 1998:23-5, 77, 88). Documentation and archiving were certainly 'intricate technologies of rule in themselves', reproducing the very state machines they derived from (Stoler 2009:20, 28), but the resultant systems of bureaucracy, registration, and documentation posed not only a threat to those attempting to avoid the state but also provided opportunities for resistance through everyday strategies of deferral and displacement (Kafka 2007:18; Szreter and Breckenridge 2012).

This article depends solely on materials produced by the colonial state and thereby follows the colonial gaze. Much of what is known of the Alfurs' precolonial lifestyles and political organization has been rendered through colonial reports and semi-anthropological works written by (former) colonial offi- 


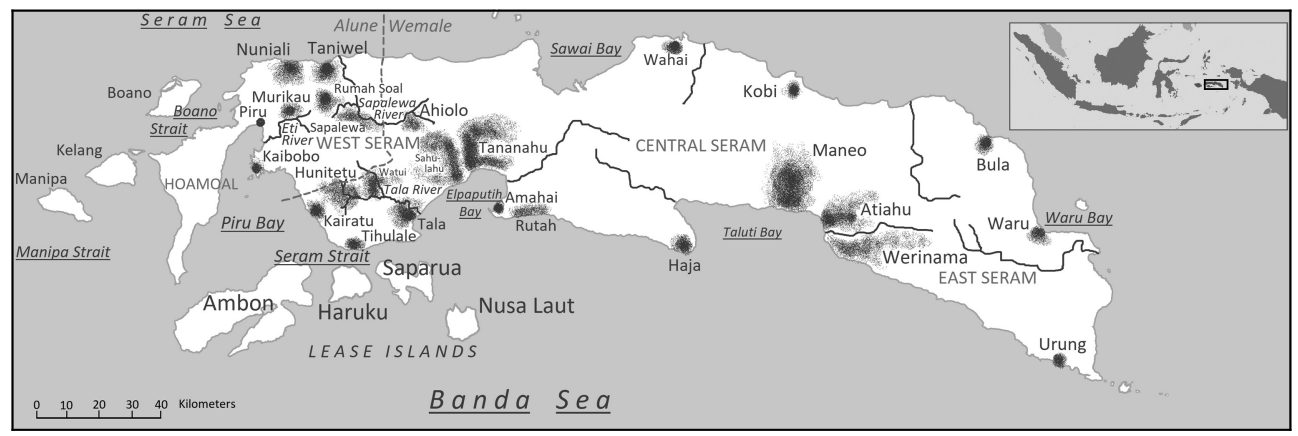

FIGURE 1 Seram

cials. $^{2}$ Hence this article does not aim to provide indigenous counter-perspectives to experiences of Dutch colonization. Rather, it argues that colonial governance was a mixed process in which the state's laws, conditions, and precepts were constantly revised, reshaped, and redrawn in the context of local interaction and exchange between European and indigenous bureaucracy, ceremony, and violence.

Ultimately, the case of Seram shows that when seen from 'peripheral margins', colonial empires provide us with many examples of interconnectivity and mutual dependence of 'rulers' and 'ruled', as a source of new ideas and practices in their own right. This helps us to further challenge perceptions of Western imperial hegemony and replace these with readings that enforce the ongoing reinterpretation of the hybridity and instability of colonial power (compare with Bhabha 1994; Ruiter 2002).

In Indonesia, a fully fledged colonial tax system emerged between 1870 and 1920, following the rapid expansion and consolidation of the Dutch modern colonial state and empire. Before 1870, the majority of the indigenous people subjected to Dutch rule paid little or no taxes; instead, they performed coerced labour in systems of agricultural production and public services. Coerced labour was claimed to possess 'disciplinary power' to stimulate

2 Because this knowledge was largely acquired only after Dutch military intervention, it is already slightly distorted by colonialism. 
colonized populations, stereotypically framed as 'lazy natives', to higher levels of production and welfare (Alatas 1977).

These systems of coerced labour exploitation became increasingly untenable against the backdrop of the increasing influence of political liberalism from the 186os onwards. This led to a revision of governance and fiscal policy, followed by a 'developmentalist' turn in the late nineteenth century that bound liberal economic policy to principles of ethical colonialism that sought to fulfil 'a moral calling' towards the indigenous population by improving local indigenous welfare and systems of colonial governance (Locher Scholten 1981; 1994:106).

Simultaneously, undergirded by notions of fierce colonial competition, the Dutch felt compelled to extend their control over Indonesia's territories to round out their political sovereignty throughout the archipelago. These concerns corrected what the Dutch might have lacked in "vehemently "imperial" pitch' (Raben 2013:9-10; Lindblad 1989:2), and fitted general norms of modern imperialism expressed in more aggressive strategies and patterns of overseas expansion.

Through unforgiving warfare and treaty-making, the Dutch tied the Indonesian archipelago together into a unified economic-political framework intertwined with civilizational projects and missionary activities. Within the imperialist project, every act of expansion was proclaimed as being to the benefit of local populations, to protect these against their own violent inclinations and promote internal development. Thus, colonial developmentalism and imperial expansion intertwined; imperial competition, exploitation, and the enlightenment of colonial subjects were deeply entangled phenomena common to all colonial empires, because colonial expansion required such legitimization to enable further exploitation (Stoler 2009:24).

'Gentle pressure' was applied to permeate village life with European social principles. Christianity and education were propagated as the heartbeat of modern civilization to nurture the abilities of indigenous peoples, and in particular its chiefs, to function in the developing colonial political economy as 'emancipated', semi-autonomous self-rulers and alleviate the workload of overburdened European officials. Thus, 'ethical colonialism' also served the legitimization of the deeper penetration of the colonial state into unexplored peripheries and into the hearts and minds of colonized people-but always through their own rulers. This way, colonialists squared imperial expansion and exploitation with developmentalism and standoffishness.

These developments both required and enabled the construction of a more modern fiscal system, which entailed three basic ambitions: the monetization of tax-levying; the centralization and unification of tax law; and the mono- 
polization of taxes by the state and replacement of tax farmers with a professional, tax-levying bureaucracy guided by laws and stipulations (Wahid 2013:24, 13-7). Taxation became a spearpoint of colonial developmentalism as taxes addressed patterns of income, property, consumption, and production, typically the elements of a society that officials aimed to transform. Taxes were actively used as governmental tools or disciplinary instruments to correct behaviour, instil productivity, and shape obedient, 'civilized' taxpaying subjectcitizens living according to the patterns desired by the state (compare with Bush and Maltby 2004; Havik, Keese and Santos 2015). In 'Outer Territories' like Seram, taxes were believed to help to keep people in place and normalize village inhabitancy, structural labour, monetization, and integration into the liberal, global political economy; to support the transition from what Europeans saw as 'unmodern social organization' into clear categories of bureaucratic governance; and to 'solve' alleged problems of innate laziness, feudalism, misrule, societal paralysis, and vagabonding (Foucault 1995:218; Stoler 2009:43). Supported by its discourses of development, progress, and civilization, the colonial state purported a governmental rationality in which colonial taxes were presented as levied in the best interest of colonized subjects. Both state and subjects were to be updated and familiarized with each other through tax payment. Ideally, taxes were levied independently by local rulers to maintain selffunded local administrations.

New income taxes were issued, first for Europeans living in the colony as well as 'Foreign Orientals' from 1878 onwards, followed by 'natives' (inlanders) in 1907. ${ }^{3}$ These taxes were unified in 1914 and $1920 .{ }^{4}$ They supposedly contributed to the redistribution of the colonial burden across the archipelago among the various, legally separated social groups alike, so that all would pay taxes to their capacity in similar, equal, and just ways. However, the colonial state remained crossed by numerous geographical, social, and economic differences that impacted the ways in which taxes were levied, inciting scepticism among officials about the effectiveness of the income taxes (Brunner 1928).

Therefore, the modernizing effect of the new taxes might have been smaller than presumed. Earlier studies of taxation in colonial Indonesia centred mostly on Java (Wahid 2013; Hugenholtz 20o8; Ong Hok Ham 1975), where modernization comprised the transition of coerced labour into monetary taxes to furnish further economic reform. Elsewhere, such as in stateless spaces like Seram, fiscal modernization was of a different nature. Monetary taxation required the

3 Staatsblad van Nederlandsch-Indië 349-352/1878, 182-183/1907.

4 Staatsblad van Nederlandsch-Indië 130/1914 and 678/1920. 
(re)standardization of subjects through techniques Dutch state officials had yet to master. It required knowledge of individual incomes and localization of individual property, in themselves problematic concepts in many of the 'Outer Territories'.

In reality, the colonial state had limited control over taxation and the tax burden. Taxation remained delegated to self-policing indigenous elites, village chiefs, tax farmers, and other intermediaries who were expected to provide information on their subjects and collect revenue from them in exchange for profit shares (Wahid 2013:178-9). Local chiefs drafted the assessments, to which people were allowed to object at so-called 'tax gatherings', during which assessments were renegotiated in the presence of European officials, and after which payments were made. The daily reality of taxation was generated in local circumstances of pragmatically informed choice rather than developed through proactive, law-based strategies intended to build solid colonial fiscal institutions. This hampered centralization and unification. Meanwhile, colonial policies of improvement got frequently overridden by metropolitan political and material interests. For instance, while the number of corvée (coerced labour) services was to be gradually reduced and replaced by head taxes, territorial expansion of the colony and the greater labour demands of enhancing the infrastructural and irrigation networks in fact caused corvée labour to increase in absolute numbers (Meijer Ranneft and Huender 1926).

\section{The Colonization of a 'Non-state Space'}

Fuelled by its expansionist drive for political and territorial consolidation, Dutch imperialism was characterized by a twofold ambition. The first was to locate and commence the exploitation of Indonesia's fertile soil, labour power, and important mineral resources. The second was to develop local society, materialize ethical-civilizational motives, and establish 'peace and tranquillity', a goal which was often informed by concerns about local violence and internal upheaval. In the case of Seram, ever since the seventeenth century, the Dutch had worried about what they perceived as growing political instability, which reached a new peak in the 186os. Before examining the causes and consequences of these dynamics, it is important to understand the social conditions of the Alfurs and their relationships with the outside world, and how these were interpreted by the Dutch. 


\subsection{Life in the 'Non-state': Stereotypes and State Alternatives}

Seram's mountainous inlands were unsuitable for large-scale rice-plantingthe prime source of state-organization, governance, and taxation in Southeast Asia-so the Alfurs remained unrestrained by agriculture or any form of forced labour and cultivation. They avoided patterns of fixed settlement, written records, and administration, keeping the development of states at bay (J. Scott 2009:9, 81-9, 229-30). Living in remote, unfixed, and dispersed settlements rather than strictly demarcated territories, they maintained a sustenance economy based on hunting, gathering, and small-scale sago-planting ${ }^{5}$ and interacted in political structures originating in socio-spiritual divisions. ${ }^{6}$

The Alfurs' nagari consisted of various relatively independent clans that adhered to leadership of a chief (kepala nagari) who usually claimed descent from a mythical village-founder and served as representative of the village to the outside world and as arbiter in adat disputes among village clans. On West Seram, communities were composed of complex family groups (luma inai, 'mother houses'). Central Seram was only populated over the course of the sixteenth to nineteenth centuries by various immigration groups that developed into units, called ipan, with claims to descent from as far as Malacca or even the Arabian Peninsula (Bartels 1994:76-7, 88-101). Soa, important Moluccan clan groups originating in Ternate, did not exist on Seram until the colonial government started grouping luma inai under newly appointed kepala soa in the twentieth century (Fraassen 1987; Boulan-Smit 1998:56).

In many Moluccan societies, specific divisions existed between ancestral groups that expressed differences in social constitution, adat, and religious and cultural practices. In (West) Seram, a distinction was made between the so-called Patasiwa and the Patalima. These formed political bonds of nagari that were considered to be each other's ritual nemesis and engaged in frequent warfare. A majority of Patasiwa men wore tattoos on their chest in the shape of a black cross. They were called Patasiwa Hitam (Black Patasiwa), while those without tattoos were referred to as Patasiwa Putih (White Patasiwa). These tattoos expressed membership of the kakean, a masculine 'secret society' or 'brotherhood' that aimed to continue the honouring of common spiritual ancestors. All Patasiwa Hitam boys had to be initiated into the kakean

5 Sago was typically depicted by colonial officials as an abundant crop requiring little effort to maintain. One family could easily live of a sago palm for a year and use its produce at will (Ruinen 1921:52-5).

6 The most important division in West Seram was between two related groups called Alune and Wemale. See Duyvendak 1926:14, 16-7; Bartels 1994:37; Jensen 1948; Sachse 1919:30-1; and De Vries 1927:9-10. 
in highly secret, secluded rituals to reach adulthood (Boulan-Smit 1998:46; Van Eerde 1920:533; Ruinen 1929:220-1). An integral cultural-religious practice associated with the kakean was headhunting, important for men to acquire greater social status but subjected to strict rules. ${ }^{7}$ Though anyone from another bloodline could be attacked (regardless of age or gender), specific forms of kinship protected against such attacks.

Another form of socioreligious partnership called pela had emerged on Ambon prior to Dutch colonization. Pela were nagari alliances that, based on 'blood-brotherhood', crossed religious boundaries and obliged the involved nagari to assist in mutual protection, assistance in times of crisis, and coordination of war and peace (Bartels 1994:29, 38-41). Though initially uncommon on Seram, there is evidence that some nagari on Seram engaged in pela bonds with nagari on Ambon, possibly in response to the encroaching colonial presence (Bartels 1977:131-45, 162-3; Sachse 1907:116-7).

Such bonds and alliances should be understood as alternative structures to larger political entities of states and centralized taxation. Security was regulated on Seram not through social contracts or tax-funded protection but through village alliances and ritual order. For centuries, war coordinated through social networks had helped to resolve political tensions and conflict among the Alfurs' fluid interior adat communities. West Seram in particular was a deeply divided society of multiple groups of nagari managing their own subsistence economies in shifting alliances to assist each other in matters of defence and economic aid. Increasing colonial presence possibly enhanced the social function of kakean, pela networks, and warfare to ward off the state. Alfurs' society as encountered by colonial officials in the late nineteenth century was the remnant of these developments.

Seen through colonial spectacles, the Alfurs were 'carefree' people who 'do not think of tomorrow' (Sachse 1907:86-7); 'hunters in the first place', living in the 'deep tranquillity of forests' as 'Bohemians of the Moluccas' (De Vries 1927:17-20). Such Rousseauan depictions of carefree tribalism-a common orientalist genre-seemingly conflict with the Alfurs' allegedly more 'violent', 'anarchistic', and 'undisciplined' characteristics (Sachse 1907:30, 32-5; De Vries 1927:81-2; Tichelman, 1925:674-5, 703-7), but both elements complemented typical colonial conceptualizations of an archetypically 'undeveloped', 'irre-

7 Men were allowed to paint a black circle on their cidako (loin cloth) when they had hunted their first head, and then to add concentric circles around this for every new head. However, most men would hunt little more than one, perhaps two heads in their lives. A man hunting more than five would 'be considered a hero of legendary allure' (Bartels 1977:38). 
sponsible', and 'childish' tribal people in need of colonial tutelary instruction to 'cure' their allegedly innate 'tendency for violence'.

To the Dutch, in contrast to the forest-dwelling Alfurs stood the purportedly more developed coastal communities. These consisted of migrants from the interior and settlers from across and beyond the archipelago. Unlike the Alfurs, the coastal communities engaged with the outside world on a more regular basis and had adopted 'governed' lifestyles of swidden agriculture, taxes, and monotheism (Boulan-Smit 1998:158; Ellen 2014:259). Across Indonesia, such a perceived distinction between developed coastal (pesisir) and ungoverned hill (hilir) societies helped colonial officials to conceptualize the character of tribal identity, which 'in Asia especially is shaped by the proximity of civilization' and defined not by social conditions, race, or ethnicity (Benjamin 2002:9) but by a 'reactive and purposeful statelessness' adapting 'to a world of states while remaining outside their firm grasp' (J. Scott 2009:337). ${ }^{8}$ Indeed, the Dutch concluded that because the Alfurs were not territorially bound but 'freely roamed around [...] their lands' as 'semi-nomadic" wanderers' (De Vries 1927:125), they were 'insusceptible to modern governance. ${ }^{9}$ As elsewhere in Indonesia, the perception became that colonial rule over the highlanders of Seram worked best through coastal intermediaries.

\subsection{War- and Peacemaking}

While in earlier stages of their presence in Indonesia the Dutch had found little reason to engage with the Alfurs, except for repelling raids targeted at Dutch outposts or 'Christian settlements' on the coast or for occasional recruitment for hongi expeditions, ${ }^{10}$ after 186 o Dutch officials became increasingly worried about the Alfurs' continuous local 'feuds', wars, and headhunting campaigns. These concerns were nourished by the need to take a firm stance against

8 Duyvendak emphasizes that there were no real cultural distinctions between coastal and mountainous villages per se, and that the contrast between pesisir and hilir on Seram should be seen only in light of interaction. The main difference was that as the coastal inhabitants were more regularly in touch with cultural influences from outside, they adapted and lost some of their 'tribal' identity (Duyvendak 1926:10; Bartels 1977:5$6)$.

9 Directeur Binnenlandsch Bestuur (hereafter DirBB) to Governor General (hereafter GG), 4-8-189o, Arsip Nasional Republik Indonesia (hereafter ANRI), Archives of the Algemeene Secretarie, Grote Bundel (hereafter AS GB) 4111, Missive Gouvernementssecretaris (hereafter MGS) 26-1-1891. See also Riedel 1886:27.

10 Annual expeditions in the seventeenth century during which the voc governor commanded a fleet of indigenous rowing boats (kora-kora) from Ambon to raid surrounding islands to enforce the Dutch monopoly on spice production. 
indigenous violence in order to exhibit credible governance that was proactively protective of its (future) subjects' general wellbeing and safety. The Dutch interpreted recrudescence of warfare and headhunting as a sign of destabilization (Sachse 1922:144). They argued that monitoring this 'violence' in itself had already cost the government valuable time and money, as officials stationed in the Moluccas found themselves increasingly busy responding to Alfurs' raids on the coast. ${ }^{11}$ Eventually, this provided self-justification for Dutch military intervention.

In the 186os, war erupted around the Elpaputih Bay (see Figure 1), when nagari Tananahu allegedly refused to pay nagari Sahulau a peace offering, or harta, of gongs and ceramic dishes as compensation for allegedly having compromised the secrets of the kakean, which was regarded as a serious crime (Sachse 1907:90; 1922:111). ${ }^{12}$ According to the local colonial administration of the time, this accusation was a 'myth', invented by chief who had been removed and sought revenge by instigating conflict. The officer in charge deemed local disputes over the borders of dusun (fishing and hunting terrains) the likelier cause of war. ${ }^{13}$ However, political, socio-economic, and religious reasons for conflict often intertwined on Seram and were rooted in various tensions of a socio-religious nature.

The potential threat of encroaching Dutch colonialism itself cannot be ignored as a factor in these tensions. In 1865, so-called nagari taxes were imposed in Ambon as an alternative to the abolished forced spice-cultivation system. A full-scale revolt broke out among a group of Patasiwa nagari that maintained pela ties with nagari on Ambon over fear that the government would soon start taxing their nagari as well. ${ }^{14}$ The chief of nagari Nuniali wrote to the Assistant-Resident in Ambon 'that his people were affected by rumours that an office would be established, taxes would be levied, and sawah would

11 Directeur van Financiën (hereafter DirFin) to GG, 6-12-189o, Nationaal Archief, Den Haag, 'Archief van het Ministerie van Koloniën', 2.10.02, 1850-1900 (hereafter NA MinKol 185019oo), 4675, Verbaal 25-2-1893 no. 44.

12 Harta came in use as compensation for and, later on, as a replacement of, hunted heads, paid by the headhunter to the victimized family. See Resident van Ambon to G G, 14-9-1891, NA MinKol 1850-19oo, 4675, Verbaal 25-2-1893 no. 44. See also Bartels 1977:54 and Ruinen 1929:226-7.

13 Resident van Ambon to GG, 13-4-1885, ANRI AS GB MGS 4111, MGS 3-6-1885. Accusing a scapegoat of sedition, motivated by religious extremism or personal grudges, was a common colonial response to any type of 'unrest'.

14 Governeur der Molukken (hereafter GovMol) to GG, 29-8-1866, NA MinKol 1850-19oo, 2126, Verbaal 19-8-1868 no. 6. 
be plotted' to impose some kind of 'coerced rice-cultivation scheme.15 Maintaining monocultures of rice traditionally enabled Southeast Asian kings to sustainably fix masses of people in domains, so the Alfurs rightfully associated rice-planting with the arrival of states and the techniques of methodical registration and taxation they sought to avoid. The kepala soa of Tanunu declared that his people 'would flee into the mountains until the government would make peace [...] and attack all nagari on Seram if the government intended to erect settlements in Nuniali and Kaibobo.' ${ }^{16}$

The contemporary governor of the Moluccas, N.A.Th. Arriëns (in office 18641866), had little choice but to give in. Though the Dutch claimed Seram as colonial territory-ministerial officials in The Hague already started emphasizing the importance of self-sufficient governance on the island-troops stationed around Seram were ill-prepared to control the interior. Seram was still 'an area where $[\ldots]$ the sheer rumour of taxation already provided sufficient ground for rebellion'. ${ }^{17}$ Arriëns advised to counter such 'rumours' by postponing taxes and using 'the softest means possible to re-establish awe and respect for Dutch authority'.18

The Dutch of course denounced that the Alfurs' resistance was targeted at the threat of the state itself and instead attributed it to the alleged violent nature of the Alfurs and the political interplay between coastal and mountainous nagari. Arriëns, for instance, accused the coastal nagari of spreading lies and stirring up the Alfurs of West Seram. According to Resident J.G.F. Riedel of Ambon (in office 1880-1883),

The Alfurs [...] live under the assumption that the 'sly coastal inhabitants' can rob them unpunishably [...]. For this reason, they exercise their own vigilante justice by hunting heads. [...] Headhunting among the Alfurs on Ceram hence takes place as a result of vengeance. ${ }^{19}$

Riedel claimed that as coastal people had a 'knowledge monopoly' on the Alfurs (no maps of the interior existed yet and few people dared to participate in expedition tours out of fear of being headhunted), they misled the European government, 'sullying the Alfurs' reputation' in an attempt to gain Dutch sup-

\footnotetext{
15 GovMol to G G, 12-10-1865, NA MinKol 1850-19oo, 1695, Verbaal 23-12-1865 no. 10.

16 GovMol to G G, 12-10-1865, NA MinKol 1850-19oo, 1695, Verbaal 23-12-1865 no. 10.

17 Nota A2, NA MinKol 1850-1900 2126, Verbaal 19-8-1868 no. 6.

18 GovMol to G G, 12-10-1865, NA MinKol 1850-19oo, 1695, Verbaal 23-12-1865 no. 10.

19 Voormalig Resident van Ambon to Minister van Koloniën (hereafter MinKol), 5-3-1889, NA MinKol 1850-190o, 4245, Verbaal 19-3-1889 no. 61.
} 
port. ${ }^{20}$ Seen as such, the coastal communities were a threat to the Alfurs as they provided the state access to the interior. Riedel advised to appoint more posthouders, the lowest-ranking colonial administrators in the Moluccas installed in the coastal regions from the seventeenth century onwards to maintain ties with the coastal nagari. Most posthouders were Indo-European and partly of local descent and 'familiar with the Alfurs' culture', which Riedel claimed would help to 'enhance relations with the Alfurs.' ${ }^{21}$

Riedel's successor, D. Heijting (in office 1883-1891) disagreed. He considered the wars an expression of a typical 'yearn for violence' inherent to the Alfurs' 'untamed nature.' Wars, he claimed, were caused by the imposition of repercussions for not paying harta resulting from 'original quarrels that no-one knew the cause of anymore', and frustrations over colonial impediments to organise kakean festivities. Such festivities were held after headhunting campaigns, which took place in retaliation for failure of payment of harta, which in return were often levied as compensation gifts for headhunting campaigns. This, Heijting argued, caused an endless circular development of headhunting and failed harta payment - a cycle, he agreed with Riedel, that could only be broken by colonial intervention. ${ }^{2}$

Other contemporary observers considered in particular the kakean a constant source of warfare and a central element in resistance to colonial rule. ${ }^{23}$ Army officer and civil-military governor of West Seram F.J.P. Sachse (in office 1903-1905) described Seram as a place where

murder and manslaughter were daily business $[. .$.$] the mountain Alfurs$ reigned with terror over others $[\ldots]$ The governing strategy at the time was one of continuous peacemaking among the tribes [...] while the mountain inhabitants were appeased with gifts $[\ldots]$.

SACHSE 1922:78

He claimed the kakean provided fertile ground for a dangerous religious, sociopolitical, and ritual fusion. (Sachse 1907:94-95), used by shrewd priests (mauweng) to extend their influence to counter 'Christianization' and 'European-

20 Voormalig Resident van Ambon to Minister van Koloniën (hereafter MinKol), 5-3-1889, NA MinKol 1850-19oo, 4245, Verbaal 19-3-1889 no. 61.

21 Voormalig Resident van Ambon to Minister van Koloniën (hereafter MinKol), 5-3-1889, NA MinKol 1850-19oo, 4245, Verbaal 19-3-1889 no. 61.

22 Resident van Ambon to GG, 14-2-189o, NA MinKol 1850-190o ov, 4675, Verbaal 25-2-1893 no. 44.

23 Van Hoëvell 1896:516, 528-32; Sachse 1907:61, 95; Van Eerde 1920:533-5; Tauern 1918:29-30, $15^{2 .}$ 
ization'. The kakean's most prominent elders had the power to call together the Saniri Tiga Air (Council of Three Rivers; the Eti, Tala and Sapalewa), the largest inter-nagari council on Seram. ${ }^{24}$ Only men initiated into the kakean were allowed to attend this saniri (council). Its organization was initially stimulated by the Dutch, as it provided one of the few occasions in which large numbers of nagari elders gathered and could be monitored. In the twentieth century, however, officials grew convinced that the saniri had become a 'vehicle for the kakean' through which 'religious enmities turned into political feuds' (Sachse 1922:138). Both saniri meetings and kakean festivities were henceforth actively opposed. Headhunting had formally been prohibited by the colonial government in 1864, though it would take until the twentieth century before this was enforced. ${ }^{25}$

In doing so, Dutch officials pursued a separation between worldly political and religious-spiritual powers in a society in which no clear border existed between these. Harta payment and headhunting campaigns were political instruments of war and peace, infused with an important religious-ritual dimension that reflected inter-nagari politics (Bartels 1977:36-42). This was symbolized in the baileo, the meeting place of the intra-nagari saniri for political discussion and adat affairs. In earlier times, hunted heads were necessary for its sanctification (Aritonang and Steenbrink 2008:109). Without enacting the accordant rituals, there was no common ground for politics to be organized. The Dutch were aware of this and across Indonesia often attempted to employ ritual for their own purposes. But in Seram, the intertwining of the saniri and kakean symptomized the need of the Alfurs to unite in the endurance of ritual in reply to the growing threat of colonial interference (Bartels 1994:40-3, 53-4). ${ }^{26}$ Non-payment of harta and the increase of headhunting

24 Also known as Saniri Waele Telu. The importance of this saniri derived from its supposed representation of the primordial ancestral groups from the core place of origin of all Alfurs and other Moluccan people, the holy mountain Nunusaku. Its meetings have been recorded since at least 1678 (Knaap 1993:251, 260-1). Each nagari also had its own saniri of village elders.

25 GovMol to GG, 23-1-1864, NA MinKol 1850-19oo, Verbaal 23-12-1865 no. 10. After 19o6, a special permit granted by the local colonial official was required for every kakean initiation ritual, each of which would require a number of heads to be hunted. Resident van Ambon to GG, 14-2-189o, NA MinKol 1850-19oo, 4675, Verbaal 25-2-1893 no. 44; Manuhutu $1985: 280-2$.

26 For more on the fusion of the saniri and kakean organizations, see Duyvendak 1926:8395. Whether Duyvendak is right in claiming that 'the unity of the kakean keeps the saniri together', that the '[kakean] might have given rise to the saniri bonds', and that 'whoever is allowed entrance to the kakean community has also gained access to the saniri council [...] gaining his civil rights' (Duyvendak 1926:94-5), is difficult to verify. Duyvendak, like 
signalled by colonial officials in the nineteenth century may have provided mechanisms to channel local tensions and continue 'violence' to repel the state (Bartels 1977:36-42). Adhering to kakean practices helped the Alfurs to sustain the foundations of their society. They always provided legitimate causes for war- the Elpaputih War was no exception-and were observed more ardently and instrumentally in response to Dutch intervention. While the Dutch understood that politics and religion mixed, they failed to acknowledge that these bonds intensified as a result of their presence. Hypersensitive to anything discordant to their narrow framework of social success, termed in isolated standards of European modernity, they interpreted the Alfurs' deliberate war- and peacemaking instruments as signs of 'instability' to legitimize their mission of interventionist civilizational colonialism. This translated to a fixation on banning the kakean, seen as the pinnacle of Moluccan 'tribalism' and 'primitiveness', hostile towards 'civilization and Christianity' and in the way of 'progress' and 'modernity'. ${ }^{27}$ This way, ritual and violence attracted instead of repelled the state.

While Dutch convictions for the need to intervene grew, governmental capacity lagged behind. Intervention required investment in administrative and military power, but the contemporary dogma of colonial 'decentralization' policy ordained the costs of local colonial administration was to be carried by locally levied $\operatorname{taxes}^{28}$ for which the Alfurs were still deemed 'unready.' ${ }^{29}$ Officials feared 'the potential unfavourable consequences of imposing taxes upon uncivilized people, giving rise to the idea that establishing ties with the government would mean having to pay up' ${ }^{30}$

Then, in 1884, the prahu of posthouder L.A. van Gent (in office 1882-1902) of Amahei was shot at by Alfurs of nagari Sahuau and a Dutch flagpole taken down - an outright expression of 'contempt' for the symbols of colonial authority that immediately reinvigorated Dutch safety concerns. ${ }^{31}$ The colonial

most colonial officials and writers, remains a bit vague about what exactly bound them together, but it can be assumed that both saniri and kakean operated on the same socialcultural plane of organization.

27 Verslag van het beheer en den staat der Oost-Indische Bezittingen, 1859, p. 16; Van Hoëvell 1896:516; Sachse 1907:95.

28 DirFin to GG, 6-12-189o, NA MinKol 1850-19oo, 4675, Verbaal 25-2-1893 no. 44.

29 As upheld by the Governor General, Raad van Indië, and the directors of the 'Interior Administration' and Finances, see GG to MinKol, 23-10-1892, Advies Raad van Indië, 2612-189o, DirBB to GG, 4-8-189o and DirFin to GG, 6-12-189o, NA MinKol 1850-19oo, 4675, Verbaal 25-2-1893 no. 44.

30 Resident Ambon to DirFin, 25-1-19o9, NA MinKol 19o1-1953 Ov, 651, Verbaal 19-6-19og no. 31.

31 See the correspondence between the Posthouder of Amahei and Resident of Ambon (let- 
military commander urged Governor General O. van Rees (in office 1884-1888) to send troops. ${ }^{32}$ At the time, the colonial army already occupied conquering and ravaging Aceh, while the battalions stationed in the Moluccas were sent out to colonize the Tanimbar, Kei, and Aru islands in the Southern Moluccas, ${ }^{33}$ so, instead, Van Rees decided to transfer a sum of money to the posthouder to settle the kakean dispute. However, the Alfurs purposefully did not accept payment by a third party, and the war continued. ${ }^{34}$

Resident G.W.W.C. baron van Hoëvell (Resident in 1891-1896), confided in more subtle means than overthrowing the existent order using military violence. He allowed for another saniri to be organized in an attempt to regain grip over interior politics and resettle relations with local chiefs. ${ }^{35}$ He believed the conceptualized opposition between coast and mountain no longer offered a fruitful basis for policy, since coastal people also engaged in headhunting. ${ }^{36}$ He advised strict monitoring of both coastal and interior nagari and restricting the payment of harta and headhunting through severe punishments. After this initial phase of 'pacification', he hoped to introduce 'head' or 'capitation taxes', fixed taxes at usually a rate of f1.oo per person per year, to fund the appointment of more administrators to guard peace and order and improve the relations among the nagari. However, the impatient Dutch imperialist agenda of military Governor Generals W. Rooseboom (1899-1904) and J.B. van Heutsz (1904-1909), did not allow for such gradual accustoming or compromise. Civilizational colonialism decreed the full subjection and enforcement of Dutch authority, order, and moral upon even the remotest parts of eastern Indonesia. This started overruling persistent arguments that the Alfurs had no potential for economic development and taxation. Around 1900 victory was proclaimed in the wars in Aceh and the Southern Moluccas, and troops under command of specially selected Aceh veterans were collected to commence a series of military campaigns into the heartlands of Seram, announcing the end of the Alfurs' relative autonomy.

ters dated 25-10-1883, 24-6-1884, 15-11-1884, and 17-12-1884) and the Resident of Ambon to GG, 31-12-1884, ANRI AS GB, 4111, MGS 5-2-1885.

32 Legercommandant to GG, 27-1-1885, ANRI AS GB, 4111, Besluit 14-2-1885.

33 Resident van Ambon to GG, 21-11-1891, 16-9-1891 and 13-1-1892, NA MinKol 1850-1900 3597, Geheim Mailrapport 1892 no. 96.

34 Resident van Ambon to GG, 13-4-1885 and MGS 29-7-1885, ANRI AS GB, 4111, MGS 3-6-1885.

35 Resident van Ambon to G G, 14-9-1891, NA MinKol 1850-19oo, 4675, Verbaal 25-2-1893 no. 44.

36 In 1888, nine Alfurs from the coastal nagari Kairatu were convicted for headhunting. Resident van Ambon to GG, 14-2-189o, NA MinKol 1850-19oo, 4675, Verbaal 25-2-1893 no. 44. 
Dutch troops stationed at Piru used targeted actions to coerce West Seramese chiefs into cooperation, but warfare in the Seramese jungle was gruelling and they were hardly able to resist the Alfurs' counterattacks. Successfully establishing colonial power required outbalancing military violence with politics and diplomacy. Resident E. van Assen (in office 1900-1905) expected a 'policy of abstinence' would incite 'over-courageousness' among the Alfurs, while undue 'chastisement with gunfire' would only cause more raids and enhance animosity towards the coastal nagari. ${ }^{37}$ Instead, Van Assen devised plans to directly contact local chiefs to establish relations. Under military escort, starting with the outpost in Piru to be manned by Sachse, the government on West Ceram would then carefully 'police' the Alfurs to enforce the prohibition on headhunting. ${ }^{38} \mathrm{New}$, government-sponsored shipping connections from South Seram to other parts of the archipelago would activate commerce and trigger a cash flow to enable the imposition of income taxes to fund the military and administration. ${ }^{39}$ To professionalize the bureaucracy, posthouders, whose intellectual capacities and administrative abilities were increasingly subject to criticism by higher-ranking officials, were to be replaced by controleurs (local administrators). ${ }^{40}$

Van Assen calculated that by importing Ambon's head tax to Seram and the Kei and Aru islands, adequate salaries for controleurs could be funded (see Table 1), actualizing the Alfurs' worst nightmare of having to pay up for their own subjection. ${ }^{41}$ Van Assen thought the coastal nagari had been influenced

37 Resident van Ambon to GG, 13-11-1903, Nota betreffende de organisatie van bestuur van het eiland Ceram en andere gedeelten van het gewest Amboina, pp. 2-3, Res. Ambon to GG, 2-9-1903, NA MinKol 19o1-1953 Ov, 244, Verbaal 6-6-1904 no. 3.

38 Resident van Ambon to GG, 13-11-1903, Nota betreffende de organisatie van bestuur van het eiland Ceram en andere gedeelten van het gewest Amboina, pp. 2-3, Res. Ambon to GG, 2-9-19o3, NA MinKol 19o1-1953 OV, 244, Verbaal 6-6-19o4 no. 3 .

39 Resident van Ambon to G G, 13-11-1903, Nota betreffende de organisatie van bestuur van het eiland Ceram en andere gedeelten van het gewest Amboina, pp. 7-8, NA MinKol 1901-1953 ov, 244, Verbaal 6-6-1904 no. 3.

40 Major Van de Siepkamp (see below) claimed posthouders were of limited development and intellect' and 'favoured their own interests over the government's' which 'contributed to the diminishment of prestige of the European government', Voorstel tot pacificatie Ceram door Civiel Gezaghebber Maj. v.d. Siepkamp, NA MinKol Politieke Verslagen en Berichten uit de Buitengewesten, 1898-1940, 2.10.52.01, 377 .

41 Resident van Ambon to GG, 13-11-1903, Nota betreffende de organisatie van bestuur van het eiland Ceram en andere gedeelten van het gewest Amboina, pp. 29-30, NA MinKol 1901-1953 Ov, 244 Verbaal 6-6-1904 no. 3. 
TABLE 1 Expected revenue of the head tax (in guilders) in Seram according to Van Assen ${ }^{\mathbf{a}}$

\begin{tabular}{lcccc}
\hline District & $\begin{array}{c}\text { Christian } \\
\text { nagari }\end{array}$ & $\begin{array}{c}\text { Islamic } \\
\text { nagari }\end{array}$ & $\begin{array}{c}\text { Interior } \\
\text { (Alfurs) } \\
\text { nagari }\end{array}$ & $\begin{array}{c}\text { Total revenue } \\
\text { (at assessment } \\
\text { of one guilder) }\end{array}$ \\
\hline Wahai & 305 & 1,189 & - & 1,494 \\
Amahei & 1,639 & 3,063 & - & 4,702 \\
Kairatu & 2,590 & 1,587 & - & 4,177 \\
Waru & - & 5,518 & - & 5,518 \\
Kei and Aru islands) & 2,222 & 6,132 & 24,148 & 32,502 \\
Total: & 6,756 & 17,489 & 24,148 & 48,393 \\
\hline
\end{tabular}

a Resident van Ambon to GG, 13-11-1903, Nota, p. 31, NA MinKol 19o1-1953 Ov, 244, Verbaal 6-61904 no. 3 .

by modern European governance sufficiently to be 'ready for taxation'.42 To forestall resistance he advised that moderate assessments at a maximum of f1.oo per person annually should be maintained. He deemed preservation of 'peace and tranquillity' essential to socioeconomic development. As such, taxes supposedly helped to impose colonial order to protect the Alfurs against their own 'violent inclinations' and secure the idea of a strong and capable state that cared for the security and wellbeing of its subjects. Only when militarily subjected, inscribed, Christianized, and taxed were they to become successful 'subject-citizens' of the colonial state, sending out a strong signal that there was no more place for headhunting or other forms of wanton violence within the colonial state's acclaimed territories.

Hereto, the Dutch used the full array of disciplinary techniques from their colonial toolbox, including structural disarmament, resettlement, enforced fixed-village inhabitancy, the removal of chiefs and destruction of local bonds between land and people to reconstitute movements and hierarchies, and the introduction of labour services and taxes. Van Assen traversed the island to negotiate with local chiefs about potential popular acceptation of a head tax. He reported that as long as the assessment would not exceed $f$ 1.oo per person the tax would be accepted. ${ }^{43}$ Additional revenue, Van Assen hoped, could be

\footnotetext{
42 Resident van Ambon to G G, 13-11-1903, Nota betreffende de organisatie van bestuur van het eiland Ceram en andere gedeelten van het gewest Amboina, p. 30, NA MinKol 1901-1953 ov, 244 Verbaal 6-6-1904 no. 3.

43 Resident van Ambon to GG, 13-11-1903, Nota betreffende de organisatie van bestuur van het
} 
acquired by abolishing the prohibition on importing liquor so that 'rather than foreign traders $[\ldots]$ the government would reap the profits [...] from alcohol sales. ${ }^{44}$ The supreme government agreed to Van Assen's plan and reserved a budget for administrative expansion on Seram. ${ }^{45}$

However, Dutch political authority remained feeble. In 1904, in Tihulale on the south coast of West Seram, villagers refused to perform the 'nagari services' for construction of the infrastructure that the government had introduced that year (Sachse 1922:85). Across the archipelago, corvée labour was used as a routinized socioeconomic instrument to 'discipline' and employ indigenous labour power for the ends of the state. However, unlike on Java for instance, where large-scale agriculture and state-development went hand in hand with land and labour redistribution schemes, such services did not exist on Seram prior to colonization. In Tihulale, people were outraged by its imposition. They assaulted their nagari chief and hung the Dutch flag upside down for Van Assen's visit and the military had to intervene to restore order (Sachse 1919:79). As a result, Van Assen became unsure as to whether it was safe to introduce head taxes in the interior. As the introduction of taxes was primarily motivated by the desire to decentralize the funding of the colonial administration (subjected populations were expected to fund their own colonization and 'civilization' process), Van Assen's plan proposed to cover the costs of the administration fully by locally imposed head taxes. After the incident in Tihulale, however, he advised excluding the interior from the introduction of taxes. Hence, the majority of calculated revenue was to be collected from coastal nagari and the Kei and Aru islands (governed under the same administrative 'Residency' of Ambon) (see Table 1), and the interior Alfurs still would not pay for their own administration. ${ }^{46}$

Dissatisfied, the central colonial government's advisory council acknowledged that ideally 'undertaking military campaigns to force people to pay' should be avoided, but nonetheless recommended that both Van Assen and

eiland Ceram en andere gedeelten van het gewest Amboina, p. 32, NA MinKol 1901-1953 ov, 244 Verbaal 6-6-19o4 no. 3.

44 Resident van Ambon to G G, 13-11-1903, Nota betreffende de organisatie van bestuur van het eiland Ceram en andere gedeelten van het gewest Amboina, p. 33, NA MinKol 1901-1953 ov, 244 Verbaal 6-6-1904 no. 3. 'Curing' alcoholism was also among the many governmental ambitions through which the government hoped to improve the Alfurs' lifestyles.

45 A2 over voorstellen voor belastinginvoering op Ceram, GG to MinKol, 7-4-1904, NA MinKol 19o1-1953 OV, 244, Verbaal 6-6-1904 no. 3.

46 Resident van Ambon to G G, 13-11-1903, Nota betreffende de organisatie van bestuur van het eiland Ceram en andere gedeelten van het gewest Amboina, pp. 15, 31; NA MinKol 19o11953 Ov, 244, Verbaal 6-6-1904 no. 3. 
Sachse be replaced, due to 'lack of leadership', with 'established army officers' who had 'earned their spurs in Aceh', in order to end the 'needless writing back and forth. ${ }^{47}$ It was no longer considered acceptable that the interior could only be accessed via the coastal intermediaries. The new governor of West Seram, Aceh veteran Major A.P. van de Siepkamp, strongly condemned the policies of his predecessors, which he interpreted as 'compromise and pandering to popular needs' fed by 'a mentality favouring ostensible peace over forceful governance. 48 Van de Siepkamp was impressed with the knowledge collected by Sachse, but thought it had been used ineffectively. In particular the Patasiwa, he asserted, 'recognized the Dutch East Indies government only in name but in fact retained a hostile attitude. $49 \mathrm{He}$ endorsed the idea that the Alfurs' grudges towards the coastal nagari caused the feuds and raids but also believed the Alfurs' 'physically agile, dynamic, distrustful and mendacious nature' required a forceful clampdown and full disarmament before head taxes could be implemented safely. ${ }^{50}$

A new series of military campaigns into the interior of West Seram subjected the nagari Hunitetu, Rumah Soal, Tala, Sapalewa, and Ahiolo in 1906 (Sachse 1922:166-81). Following the example of Aceh, Seram was subsequently ruled by military officials. Instead of premeditated ideologies and ambitions of peaceful compliance, the Dutch ultimately resorted to militarism to counter resistance, all in name of 'development' and 'improvement'. Violence, a core trademark ascribed to the Alfurs, became the pivot of Dutch rule. A last desperate uprising' occurring in the area around Sapalewa in 1915, when kakean rituals were (once again) prohibited, was brutally quelled. The involved people were forcefully moved closer to the coast (Sachse 1922:186).

47 Advies Raad van Indië, 10-3-1905, NA MinKol 1901-1953 ov, 354, Verbaal 13-1-19o6 no. 67; Eerste Gouvernementssecretaris to Legercommandant, 11-3-1905, NA MinKol 1901-1953 ov, 354, Verbaal 25-4-1905 no. 28.

48 Voorstel tot pacificatie Ceram door Civiel Gezaghebber Maj. v.d. Siepkamp, NA MinKol Politieke Verslagen en Berichten uit de Buitengewesten, 1898-1940, 2.10.52.01, 377 .

49 Van de Siepkamp claimed that before Van Assen's and Sachse's terms, the 'tribal division' between Patasiwa and Patalima tribes was unknown, even though Riedel's De sluik- en kroesharige rassen (1886) mentions this distinction. Commandant van de mobiele colonne te Seram to G G, date unknown, NA MinKol 19o1-1953 ov, 444, Verbaal 21-3-19o7 no. 4.

50 Commandant van de mobiele colonne te Seram to GG, date unknown, NA MinKol 19o11953 Ov, 444, Verbaal 21-3-1907 no. 4. 
This forceful intervention paid off. By the end of 1906, many uncooperative chiefs were removed, weapons confiscated, kakean rituals prohibited, and people regrouped and relocated (Sachse 1907:73; 1919:84-95; 1922:95, 178). The Alfurs were inscribed on the tax registers according to which all had to live in fixed village establishments under a designated chief. ${ }^{51}$ Smaller communities of related or allied hamlets too small to effectively control and tax were regrouped as much as possible into sizeable soa and nagari (Ruinen 1929:228; BoulanSmit 1998:57). Alfurs' society was gradually disclosed, which was believed to enable its regulation, surveillance, and pacification. Sachse (1919:74) reported that

the mountainous Alfurs abandoned their provocative, rash attitude and followed [Dutch] orders quite well [...] the coastal population renounced its indolent attitude and nagari were rebuilt [...] so that people stopped wandering and the interior was repopulated.

Crucial to the colonial project of reconditioning society was the cooperation of indigenous chiefs, whose interests rarely aligned fully to those of the Dutch. Colonial empires were typically characterized by deficiencies in manpower and administrative capacity, and relied on layers of indigenous middlemen and ruling classes for both the provision of information and the execution of policies. In Indonesia, access to indigenous rulers often depended on the existence of local internal divides among warring factions, which provided the Dutch with opportunities to intermediate and enter as 'stranger-kings' (Henley 2002). In Seram, by remaining deliberately blind to local hierarchies, the Dutch broke through established patterns of rule and the alleged 'violent cycle' of retribution and revenge. Rather than absolute statelessness, rulers favoured semi-incorporation into foreign regimes to control their relations with states. This also provided them with opportunities for social climbing, albeit at the cost of much jealousy (Henley 2002:10-1, 89). This 'jealousy', and the coercive power of military intimidation, impelled the majority of the Alfurs' chiefs to accept Dutch supremacy nominally in exchange for a position in the colonial civil service. They were elicited to accept Dutch supremacy by signing con-

51 Resident van Ambon to GG, 12-1-1914, NA MinKol 19o1-1953 OV, 1230, Verbaal 14-8-1914 no. 41. 
tracts promising them greater power and wealth, and were elevated from family representatives and adat arbiters to fully fledged village chiefs awarded with titles and salaries.

These chiefs were selected for fluency in Malay and loyalty to the Dutch instead of their administrative skills or ties with local communities (Ruinen 1929:228-9), so that inheritance lines were broken and social orders remodelled (Boulan-Smit 1998:51; Tichelman 1925:696-8). They were rewarded or punished based on the revenue they collected. The primary interest of chiefs became to keep providing the state with enough information and tax revenue to keep it satisfied, while maximizing their own wages by retaining and taxing as many people as possible.

Simply giving the local chiefs canes, suits, and titles did not ensure communication of the colonial governmental agenda, even though they remain important in validating claims to power (Ellen 1997). Much of their new status depended on expressing power rather than true administrative capacity. The paper bureaucracy of the state, with its registration forms, ordinances, and tax bills, was complemented by ritual performances and regal displays which were made official by the state to generate the impression of a hybrid fusion of modern and traditional statecraft.

Figure 2, a photo shot around 1905 during a visitation tour of Sachse, depicts four village elders of West Seram who had been appointed as rulers in the Dutch colonial administration. Showing them bearing foreign titles such as patih and orang kaya, wearing European suits and hats, and holding the relevant paraphernalia including tongkat (canes with golden or silver knobs), this photo is indicative of the status awarded to them, supplementing in majesty what they lacked in power. As the smartly attired, indirect rulers of Seram, these chiefs were supposedly icons of the just colonial administration, serving and representing an immaculate, information-hungry state to support fair taxation and legal, rightful rule, and heralding a new era of peace (the Pax Neerlandica), social development, and improvement imbued with the strong tones of the forceful civilizational colonialism of the early 19oos. But behind this curtain of authority and stateliness stood a reality starkly in contrast with what the photo attempts to express.

Theoretically, 'emancipation' would gradually educate indigenous rulers by handing down authority in the hope that these rulers would pick up on the modern instrumentation the state provided. But by internalizing local hierarchy, knowledge, and adat, inherent practices of rule, power, and mediation were incorporated along with it. Seram's rulers were selected and appointed based on practical choices informed by the desire to develop an administration as quickly as possible to enable taxation. 


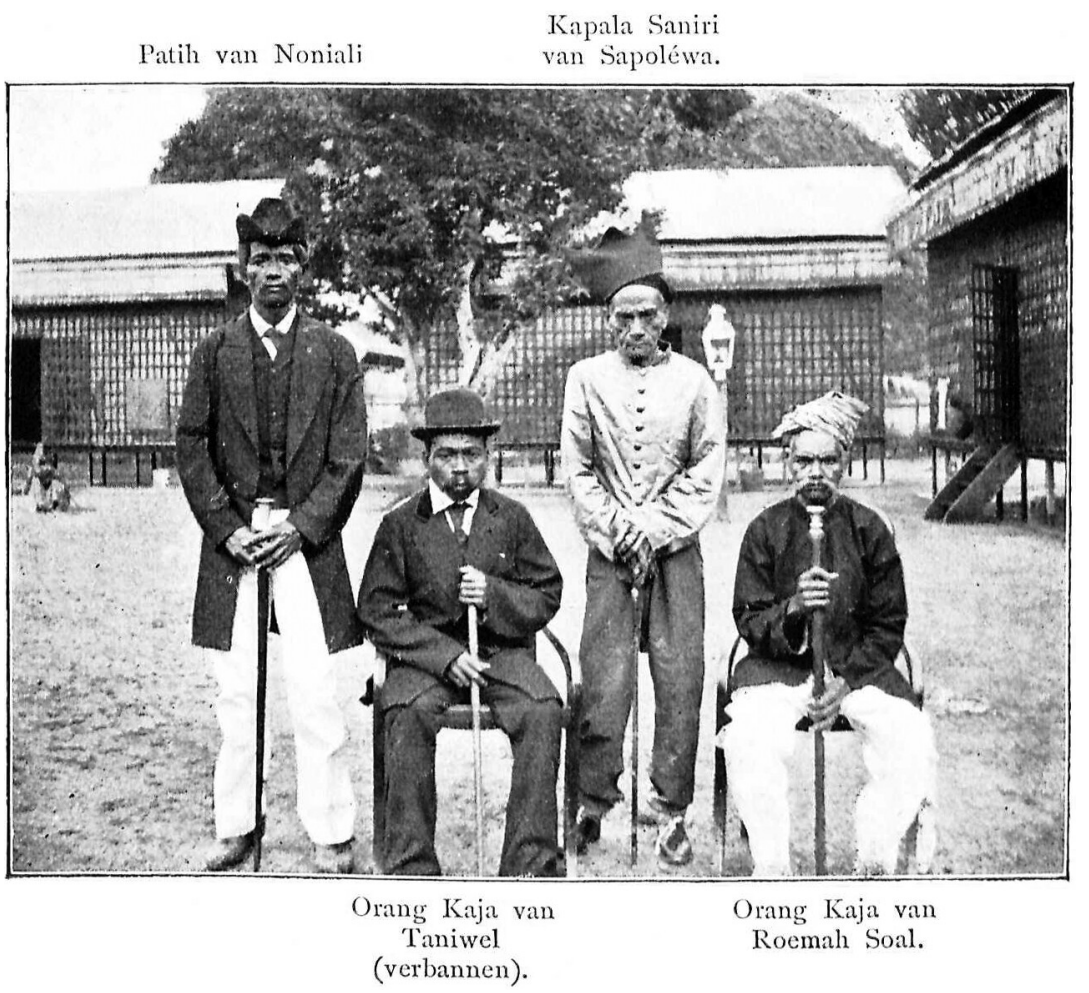

FIGURE 2 Alfur chiefs on West Seram, c. 1905 SACHSE 1907:60

As elsewhere in Indonesia, they received an $8 \%$ 'collection wage' of tax revenue and a number of labour services. ${ }^{52}$ These purportedly incited them to maximize their charge on people's incomes to make the local administration fully self-sufficient and further the self-improvement of their subjects through the imposition of taxes. According to Sachse, revenue shares 'incited regents to devote themselves to the hygienic care of their subjects, to diminish the number of deaths and increase the number of marriages and births' (Sachse 1922:134-5). But since administrating and travelling on Seram was a burdensome and costly endeavour, these 'regents' held full sway over the organization of the tax system - the execution of censuses, drafting of assessments lists, and collection of taxes. This rendered many opportunities for 'manipulation' and 'corruption', especially since they were self-rewarded based on the

$5^{2}$ Until 1905, 'collectors wages' were also awarded to (Indo-)European officials on the Outer Islands, providing a handsome addition to their incomes. 
amount of taxes they collected (Sachse 1907:71-2). The chiefs eagerly accepted Dutch supremacy to use their new power as expressed in regalia and paperwork to their own benefit. The state barely controlled interior politics and only interfered in case of disruption, which compromised its agenda of equality, justice, and social improvement.

Emancipation politics enabled the state to remain 'standoffish' and minimize the burden on the European administration (Slater and Kim 2015). By designating governance to previously distrusted 'tribal chiefs', the need to structurally expand the ability to accumulate knowledge and to maximize colonial power was reduced, much to the advantage of the parsimonious state, which ordained that taxes had to be collected at minimal expense to ensure maximal efficiency. Seram's challenging landscape and social environment made supervision a problematic endeavour, enabling the chiefs to further manipulate the state's instruments to their own ends.

The role of 'modern statecraft' and governmentality in colonial states, as identified in censuses, land surveys, knowledge production, law-making, and codification, should therefore be reconsidered. It seemed that in places like Seram, state officials solved questions of inefficiency by strategically delegating the burden of administration to indigenous elites rather than accumulating knowledge to dominate and improve society. They passed both the state's fiscal-administrative burden and responsibilities on to indigenous society itself. Accordingly, tropes such as the 'lazy native', the 'oriental despot', and the 'uncivilized headhunter' were cultivated instead of 'solved', as they provided the Dutch with a reason for the continuation of their empire. The Dutch knew harmonizing social improvement through economic development within the administrative framework of indirect rule was impossible, so in the case of Seram's colonization, indirect rule served as a double vehicle for administrative pragmatism and colonial self-legitimization.

In 1906 the coastal nagari were subjected to a head tax, which yielded about $f_{14}$,ooo to $f 19,500$ in $1906-1907 .{ }^{53}$ But to enhance 'equity and fairness', a maximum amount of 'taxpayers' had to be included; from 1906 onwards, the coastal communities paid for the 'burden of governing' the interior Alfurs. Van Assen's successor, A.J. Quarles de Quarles (1905-1908), deemed the time had come to 'teach the Alfurs that the consequences of their subjection to Dutch authority $[\ldots]$ came with taking part in public expenses, ${ }^{54}$ De Quarles agreed that the

53 Staatsblad van Nederlandsch-Indië 76/19o6; Verslag Resident van Ambon to G G, 20-4-19o6, 20-5-19o6, and 2-7-1906, NA MinKol 19o1-1953 OV, 244, Verbaal 21-3-19o4 no. 4.

54 Resident van Ambon to GG, 11-9-19o6, ANRI AS GB, 1522, Besluit 5-5-1907/MGS 5-05-1907. 
Alfurs were difficult to tax due to their 'unaccustomedness to structural labour' and 'unfixed residency', but he also believed that imposing taxation would generate

even better acquaintance with land and people, as officials [...] would travel the regions for the assessments, dotting i's and crossing t's, establishing even closer relations between taxpaying people and our administration. ${ }^{55}$

This would expedite the government's fiscal grip on the interior, as De Quarles ambitiously assured. Moreover, taxation, he claimed, would 'crucially [...] stimulate them to bring the products of their lands [...] to a market to exchange these for money'.56 To De Quarles, taxes were instrumental to both further the reception of colonial governance and uplift the Alfurs to a higher stage of monetization and economic development. But the conservative director of the colonial Department of Finances was sceptical about these 'bold theories'. He feared that, when established through taxation, relations between the state and the people would remain weak, hostile, and unconsolidated. Using taxation as a means to assess the lay of the land, the director wrote, was a precarious strategy and a matter of 'putting the cart before the horse'. Failure to implement taxes could be interpreted as a sign of weakness and undermine Dutch authority. Taxes, the director wrote, were a 'final administrative stage', only to be implemented in regions that were fully 'pacified. ${ }^{57}$ So Seram was made into an example once again. Seen through the scope of the supreme government, the interior was not deemed worth the trouble of risking further upheaval or squandering the budget, the greatest of colonial-administrative sins.

In 1909, Governor General A.W.F. Idenburg (in office 1909-1916) took office. Devoted to the ethical programme of education, emancipation, and decentralization, he appointed a more progressive director of finances. De Quarles's successor, G. Sieburgh (in office 1908-1910), reissued the tax plan, agreeing that taxes had 'educative cogency'. As long as 'excessive fiscalism' was avoided,

Resident van Ambon to GG, 10-2-19o8, NA MinKol 19o1-1953 Ov, 587, Verbaal 30-9-19o8 no. 6 .

56 Resident van Ambon to GG, 11-9-19o6, ANRI AS GB, 1522, Besluit 5-5-19O7/MGS 5-5-1907.

57 DirFin to GG, 4-3-1907 and Resident van Ambon to DirFin, 3-12-19o6, ANRI AS GB, 1522, Besluit 5-5-19o7/MGS 5-5-1907; DirFin to GG, 13-6-19o8, NA MinKol ov, 587, Verbaal 30-91908 no. 6. 


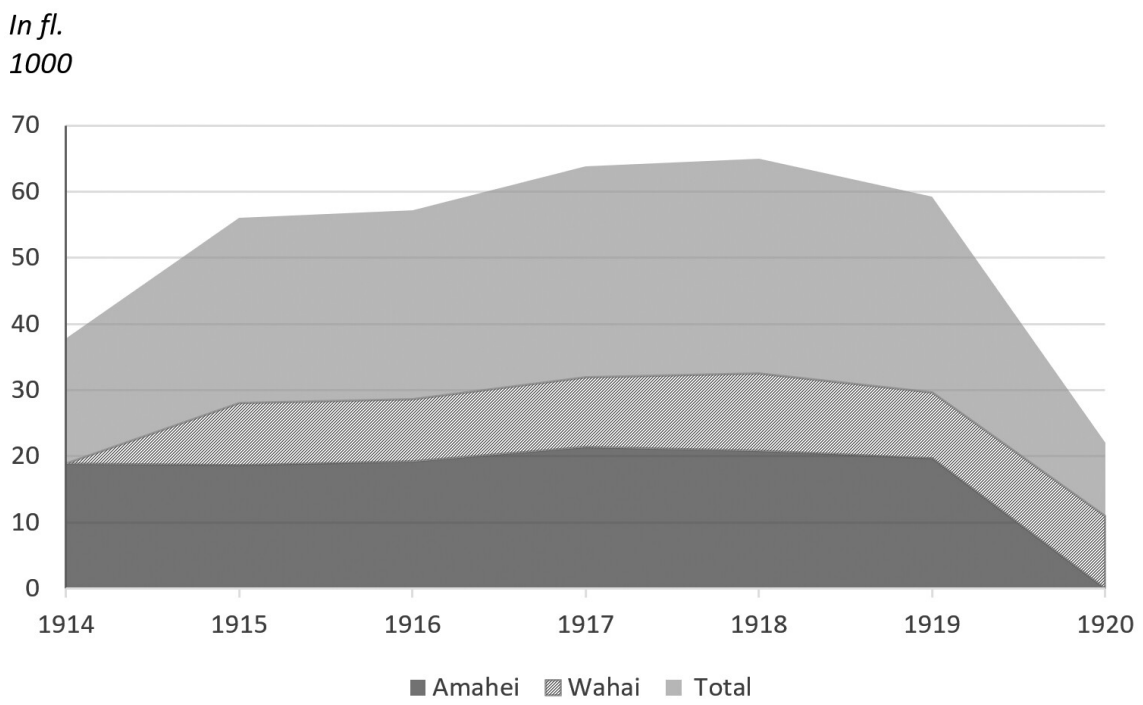

FIGURE 3 Income tax revenue levied from indigenous peoples in Amahei and Wahai, 19141920

he claimed, the Alfurs would realize the 'benefits of paying taxes'.58 Sieburgh gained approval from the new director and introduced a head tax of $f_{2}$ to $f 7.50$ over the whole island in 1910. In 1914, the head tax was replaced with a general company tax in Amahei and Wahei, issued for the indigenous and 'Foreign Oriental' population of the entire archipelago, with a flexible rate of fo.4o tax per f10.00 income. ${ }^{59}$ In $1914-1920$, an average amount of $f 5.30$ per person was collected in Amahei and Wahai, and revenue showed steady growth until the colonial post-World War I recession (see Figure 3 and Table 2). ${ }^{60}$

The imposition of these taxes was seen as a successful societal intervention. Around 1920, the Alfurs paid above the archipelago-wide assessed average tax rate for indigenous people in the Outer Islands (Fievez de Malines van Ginkel 1929:24-9, 53-4). De Quarles reported 'eager, swift and timely tax payment'.61 Sachse signalled a significant reduction in payment arrears and predicted how further institutionalization of corvée would help to counter alcoholism and instil 'greater obedience' and 'respect for authority' (Sachse 1922:19o). ${ }^{62}$

$5^{8}$ Memorie van Overgave G. Sieburgh, Ambiona, 1910, NA MinKol Memories van Overgave, 2.10.39 (hereafter $\mathrm{MvO}$ ), 312 .

59 Staatsblad van Nederlandsch-Indië 132/1914.

6o Sachse 1922:145. For Wahai in 1910 and Amahei in 1920, data are missing.

61 MvO A.J. Quarles de Quarles, Ambiona 19o8, NA MinKol MvO, 311.

62 Resident van Ambon to GG, 20-5-19o6, NA MinKol 19o1-1953 OV, 444, Verbaal 21-3-19o7 
TABLE 2 Income tax revenue raised from indigenous peoples in Amahei and Wahai, 1914-1920

\begin{tabular}{lccccccc}
\hline & 1914 & 1915 & 1916 & 1917 & 1918 & 1919 & 1920 \\
\hline Amahei & $18,9 \circ 9.2$ & 18,719 & 19,245 & $21,391.60$ & $20,824.80$ & $19,760.80$ & - \\
Wahai & - & $9,313.6 \circ$ & $9,361.20$ & $10,539.6 \circ$ & $11,672.40$ & $9,892.20$ & $11,009.3 \circ$ \\
Total: & $\mathbf{1 8 , 9 0 9 . 2}$ & $\mathbf{2 8 , 0 3 2 . 6 0}$ & $\mathbf{2 8 , 6 0 6 . 2 0}$ & $\mathbf{3 1 , 9 3 1 . 2 0}$ & $\mathbf{3 2 , 4 9 7 . 2 0}$ & $\mathbf{2 9 , 6 5 3}$ & $\mathbf{1 1 , 0 0 9 . 3 \circ}$ \\
\hline
\end{tabular}

SACHSE 1922:145

G.L. Tichelman, the controleur of Amahei (1918-1922), celebrated the 'educative effects' taxation had demonstrated as the Alfurs, he claimed, easily met their tax assessments by performing a few days of extra labour to earn cash, without experiencing a higher burden. ${ }^{63}$

Such reports concealed a reality of structural resistance. People were regularly reported to have 'escaped' their villages to evade inscription, tax assessments, and coerced labour, and forced settlement was experienced as a restriction of freedom (Boulan-Smit 1998:53-6). ${ }^{64}$ Some constructed 'fake', provisional, ramshackle houses at the coast, which they only inhabited during government inspection tours. Others secretly organized kakean meetings to continue initiation rituals to avoid full conversion to Christianity, which was believed to expedite inclusion into the colonial state's registration network. Many refused to be registered or reveal their names and took off into the forests before the tax gatherings took place. ${ }^{65}$ Tax revolts broke out in Maneo and Amahei in $1915,{ }^{66}$ which Sachse attributed to 'deeply rooted disillusionment and dissatisfaction regarding the prohibition of kakean' (Sachse 1919:101). ${ }^{67}$ Only under the structural implicit threat of military violence were the Dutch able to

no. 4. According to Sachse, 'regular labour, supervision of hygiene and especially the prevention of the opportunity to drink sago wine' by imposing corvée services was 'to the benefit of the people'. Sometimes taxation and corvée conflicted; in 1915, work on the road between Murikau and Piru was temporarily suspended to enable the people to pay their taxes (Sachse 1919:20, 32-5, 37-8).

63 MvO G.L. Tichelman, Amahei, NA Collectie 133 G.L. Tichelman, 1907-1940, 2.21.097.01, 7 .

64 Resident van Ambon to GG, 12-1-1914, NA MinKol 1901-1953 ov, 1230, Verbaal 14-8-1914 no. 41. See also Manuhutu 1985:298-9 and Tauern 1918:177.

65 Resident van Ambon to GG, 12-1-1914, NA MinKol 19o1-1953 ov, 1230, Verbaal 14-8-1914 no. 41.

66 MvO H.J.A. Raed van Oldenbarnevelt, Ambiona 1915, NA MinKol MvO, 313; MvO W.D. van Drunen Littel, Amboina 1918, NA MinKol MvO, 314.

$67 \quad$ Staatsblad van Nederlandsch-Indië 15/1910. 
enforce village inhabitancy and payment of tax, but even the threat of violence was wielded both ways: small-scale revolts kept occurring, and guns remained widely available on the island (Sachse 1922:87-91; 1922:85; Manuhutu 1985:277$8,293-5)$.

This fragile condition of the state provided competitors with an opportunity to test the boundaries of the state. In 1922, villagers in the nagari of Rutah refused to perform nagari services. It appeared the entire population had joined the anti-colonial nationalist party Insulinde, which had told them that membership of the party removed their obligation to perform services and pay taxes (Chauvel 1990:96). According to Tichelman, this rendered 'the small nagari man the scapegoat of sly Insulinde leaders' ${ }^{68}$ The typical colonial reflex was to catch the alleged 'instigators' and restore colonial political order, but officials had found an able competitor that caused them to lose their grip on the Alfurs through issues of taxation. As elsewhere in Indonesia, new players shaped a reality of political awareness and activism that in the long term could and would not be contained. ${ }^{69}$

Figure 4 displays Controleur Tichelman and his wife preparing for Queensday at their house in Amahei (the 'W' stands for Queen Wilhelmina). Photos like these portray the image of a strong, unified state and peaceful, orderly life in what used to be the domain of violent headhunters. But Amahei was only a stone's throw away from Rutah, symbolizing how the concrete authority of the Dutch government reached perhaps not much further than the controleur's house.

\section{5}

\section{Conclusion}

The Dutch colonization of Seram was motivated by the threat posed by the Alfurs' alleged unbound, 'violent', and stateless lifestyles to the continuation of the Dutch empire and its truth-regime of progress, security and improvement. With every act of violence or headhunting-campaign committed by the Alfurs, these concerns were invigorated. In the modern colonial state, there was no room for such violence or any alternative strategies of social organization. The sacred formula of European administrative governance sought to include all without exception to cure 'social deviance', such as headhunting (for which

68 Gezaghebber van Amahei to Assistent-Resident van Seram, 17-4-1920, NA MinKol 19o11953 OV, 2406, Verbaal 12-4-1922 no. 37.

69 Resident van Ambon to GG, 22-4-1920, NA MinKol 19o1-1953 Mailrapporten 135, Mailrapport 1920 no. 553 . 


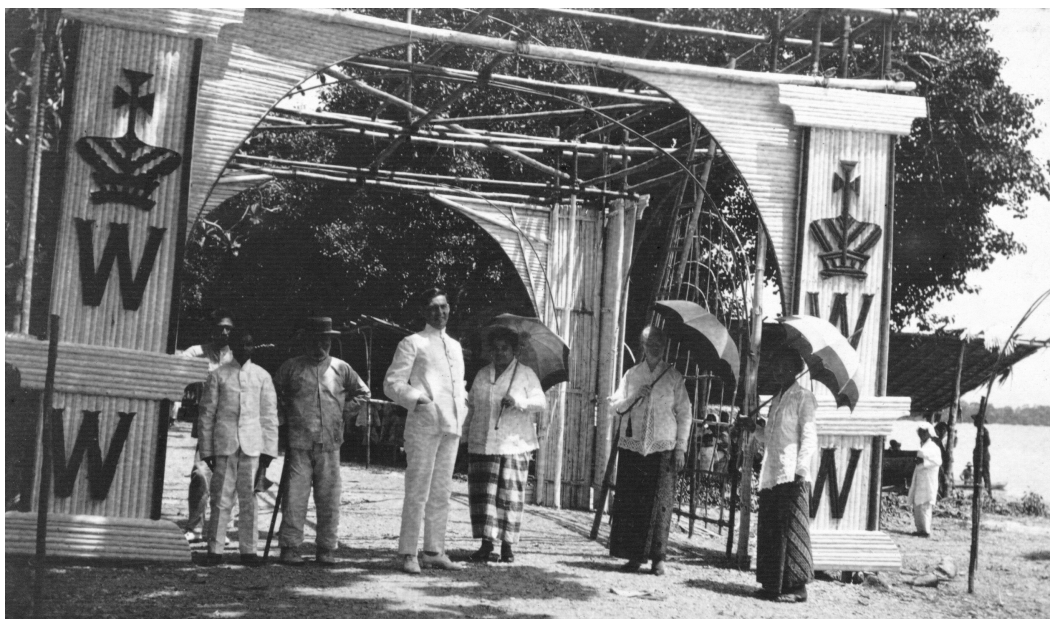

FIGURE 4 G.L. Tichelman, his wife, and local notables preparing for Queensday in Amahei, c. 1920

UBL, KITLV A185, 83518

the Dutch developed a true obsession) or impermanent residence. The urge to 'solve the problem' of inherent violence and headhunting was seen as essential not merely to protect coastal inhabitants or other Alfurs, but also to send out the clear message that within the empire there was no place for 'random' violence. This was done so as to maintain the image of credible and legitimate colonial rule and order in the eyes of the colonizers and colonized within and outside the Indonesian archipelago. Hence, the Dutch discarded the Alfurs' intertwined patterns of public, religious, social, and spiritual order, expressed in secret societies, ritual warfare, and peacemaking, as perpetual 'mindless violence' born out of 'vengeful', 'barbaric', 'uneconomic', and 'self-destructive' behaviour symptomatic of the indigenous inability to even aspire sociocultural 'progress', 'civilization', and 'modernity'. Through typical discursive practices of knowledge-gathering, the Alfurs were epistemically essentialized into a category of 'dangerous, uncivilized headhunters', which enabled the 'legitimate' colonization of Seram's interior.

The colonial 'will to improve' was substantially expressed through taxation, which was associated, by both the Dutch and the Alfurs, with structural, settled agricultural labour, permanent residence, and fixed property and incomein short, with lives registerable on paper. Taxes offered officials the rational empowerment to break down local obstructions to their state; install a local, self-funded government; 'correct' and discipline specific behaviour; and funnel socio-political reorganization. By subjecting the Alfurs and imposing taxes, the colonial state self-legitimated and confirmed its status as the lawful power- 
holder in Indonesia. Thereby, taxes were at the forefront of a colonial modernity 'concerned above all with disabling old forms of life, by systematically breaking down their conditions, so as to oblige new forms of life to come into being' (D. Scott 1995:193).

Once tamed and inscribed into tax registers under supervision of elevated chiefs, the Dutch expected the Alfurs to automatically subscribe to the idea of colonial progress and recognize the 'benefits' of benevolent imperialism. In the Alfurs' unwillingness to 'cooperate', the Dutch saw a confirmation of their truth-regime; clearly, they were still 'unready' for modern governance and unfit to be conditioned by colonial taxation towards greater forms of productivity and prosperity. Continuation of violence 'legitimized' forceful military intervention, conversion, and reform, while internal divisions among various groups and between coastal and interior communities furnished the entrance of the Dutch as 'stranger-kings' to elicit local rulers into the schemes of Dutch indirect rule-by-distance. Instead of supervising the Alfurs via coastal intermediaries, the Dutch appointed 'puppet rulers' to whom the system of governance and taxation was largely outsourced. Thereby, the Dutch upheld the image of a supposedly almighty, unified, and equitable tax state, while in reality the operation of the tax system, its profits, and the power to collect and provide the state with information based on tax assessments, were largely handed over to these rulers, who were hence incited to focus on maximal extraction and enhancement of their symbolic power rather than on carrying out the colonial developmental agenda. In order to retain the idea of efficient, local, self-funded governance by 'emancipated' rulers, the Dutch blamed the inherent problems indirect rule caused on the alleged 'innate' shortcomings of indigenous society. These 'shortcomings' comprised the agency and ingenuity of the Alfurs in manipulating policies of the colonial state. This was no unintentional effect only made possible by the ineffectiveness of colonial practice but rather an active strategy of seizing opportunities to respond to, mediate, and minimize the effect of colonial governance by continuing culturally inscribed practices to maintain stateless lifestyles.

On paper, the Dutch colonization of interior Seram seemingly exemplifies typical state-practices of knowledge-gathering, registration, and social reform. But below the surface of ordinances, registers, and hefty paperwork, it was a process of compromise and adaptation, rooted in sedulous attempts to enforce symbolism and ritual, making up in appearance for what was lacking in power. Dressing up chiefs or erecting triumphal arches for Queensday symbolized rule but did not embody or decree it. The far-reaching governmental ambitions of Dutch policies were not achieved by handing out titles and sceptres but depended on changing the realities of popular resistance and the interactions 
of chiefs and administrators on site. Half-hearted pretensions that Seram was just another peaceful, self-sufficient, productive society incorporated into the unified colonial state could not conceal that the Dutch state perpetually relied on its bond with local, indigenous ruling structures and occasional, violent enforcement of its acclaimed authority. All the while, it was also vying for influence over the indigenous society with local entities, which ranged from ritualpolitical institutes like the kakean and pela networks to nationalist parties.

This shows that colonial governance was not a unidirectional, overwhelming transition of knowledge and data into a centrally formulated policy; rather, it was a reluctant process of endless bureaucratic head-scratching and careful deliberation, characterized by deal-brokering, improvisation, and astute strategies of evasion and resistance. The state's presence in itself demanded interaction and engagement, but state-tools of registration and inscription were constantly evaded and modified. People escaped the state through resilience, desertion, and migration, and even the perpetual looming threat of violence was continuously used by both sides - though as a means of resistance it lost popularity as the Dutch had proven equally, or perhaps more violent, than the Alfurs.

Hybridity was indeed at the core of colonial encounters (Bhabha 1994:21, 89, 111). Within the colonial relationship, adaptation occurred as each side internalized traits of the other. Tax schemes and administrative practices were worked out through interaction between Dutch colonizers and indigenous societies, through pragmatism and resourcefulness. The realms of officials, middlemen, and subjects integrated and merged, undermining the separation of class, power, and position upheld by the state, while reconstituting new forms of colonial practices and knowledge and changing the colonial state from within.

\section{Acknowledgements}

I would like to thank Hans Hägerdal, Youngmin Kim, Jongtae Lim, Henk Schulte Nordholt, Nira Wickramasinghe, and two anonymous reviewers for their input and feedback on earlier versions of this paper.

\section{References}

\section{Unpublished Sources}

Arsip Nasional Republik Indonesia (ANRI), Jakarta, Algemeene Secretarie (Grote Bundel), 1522 and 4111 . 
Nationaal Archief, Den Haag, Archief Ministerie van Koloniën:

- 1850-1900

- 1695: Verbaal 23-12-1865 no. 10

- 2126: Verbaal 19-8-1868 no. 6

- 4245: Verbaal 19-3-1889 no. 61

- 4675: Verbaal 25-2-1892 no. 44

- 1901-1953, Openbaar Verbaalarchief (ov):

- 244: Verbaal 6-6-19o4 no. 3

- 354: Verbaal 13-1-19o6 no. 67

- 444: Verbaal 21-3-19o7 no. 4

- 651: Verbaal 19-6-19o9 no. 31.

- 587: Verbaal 3o-9-19o8 no. 6

- 1230: Verbaal 14-8-1914 no. 41

- 2406: Verbaal 12-4-1922 no. 37

- 1901-1953, Mailrapporten:

- 135: Mailrapport 1920 no. 553

Politieke Verslagen en Berichten uit de Buitengewesten, 1898-1940, 377.

Memories van Overgave, 311, 312, 313, 314.

Collectie 133, G.L. Tichelman, 1907-1940, 7 .

\section{Published Sources}

Alatas, S.H. (1977). The myth of the lazy native: A study of the image of the Malays, Filipinos and Javanese from the 16th to the 2oth century and its function in the ideology of colonial capitalism. London: F. Cass.

Aritonang, J.S. and K.A. Steenbrink (2008). A history of Christianity in Indonesia. Leiden and Boston: Brill.

Bartels, D. (1977). Guarding the invisible mountain: Intervillage alliances, religious syncretism and ethnic identity among Ambonese Christians and Moslems in the Moluccas. [PhD thesis, Cornell University, Ithaca.]

Bartels, D. (1994). In de schaduw van de berg Nunusaku: Een cultuur-historische verhandeling over de bevolking van de Midden-Molukken. Utrecht: Landelijk Steunpunt Edukatie Molukkers.

Benjamin, G. (2002). 'On being tribal in the Malay world', in: G. Benjamin and C. Chou (eds), Tribal communities in the Malay world: Historical, cultural and social perspectives, pp. 7-76. Singapore: ISE AS.

Bhabha, H.K. (1994). The location of culture. New York: Routledge.

Boulan-Smit, M.C. (1998). We, of the banyan tree: Traditions of origin of the Alune of West Seram. [PhD thesis, Australian National University, Canberra.]

Boulan-Smit, M.C. (2006). 'Traditional territorial categories and constituent institutions in West Seram: The Nili Ela of 'WELE Telu Batai and the Alune Hena of 
Ma'saman Uwei', in: T. Reuters (ed.), Sharing the earth, dividing the land. Land and territory in the Austronesian world, pp. 157-77. Canberra: ANU Press.

Brunner, O.R.E. (1928). De unificatie van het belastingstelsel in Ned.-Indië. Weltevreden: Kenanga.

Bush, B. and J. Maltby (2004). 'Taxation in West Africa: Transforming the colonial subject into the "governable person", Critical Perspectives on Accounting 15-1:534 .

Chauvel, R. (1990). Nationalists, soldiers and separatists: The Ambonese islands from colonialism to revolt, 1880-1950. Leiden: KITLV Press.

Cohn, B.S. (1996). Colonialism and its forms of knowledge: The British in India. Princeton: Princeton University Press.

Duyvendak, J.P. (1926). Het kakean-genootschap van Seran. [PhD thesis, Leiden University, Leiden.]

Eerde, J.C. van (1920). 'Gegevens betreffende de onder-afdeeling West-Ceram', Tijdschrift van het Aardrijkskundig Genootschap 37-4:531-5.

Ellen, R.F. (1997). 'On the contemporary uses of colonial history and the legitimation of political status in archipelagic Southeast Seram', Journal of Southeast Asian Studies 28-1:78-102

Ellen, R.F. (2014). Nuaulu religious practices: The frequency and reproduction of rituals in Moluccan society. Leiden and Boston: Brill.

Fievez de Malines van Ginkel, H. (1929). Verslag van den belastingdruk op de inlandsche bevolking in de Buitengewesten. Weltevreden: Landsdrukkerij.

Foucault, M. (1995). Discipline and punish: The birth of the prison. 2nd ed. New York: Vintage Books.

Fraassen, Ch.F. van (1987). Ternate, de Molukken en de Indonesische archipel. Van soaorganisatie en vierdeling: Een studie van traditionele samenleving en cultuur in Indonesië. [PhD thesis, Leiden University, Leiden.]

Havik, P.J., A. Keese and M. Santos (eds) (2015). Administration and taxation in former Portuguese Africa, 1900-1945. Newcastle upon Tyne: Cambridge Scholars Publishing.

Henley, D. (2002). Jealousy and justice: The indigenous roots of colonial rule in northern Sulawesi. Amsterdam: vu Uitgeverij.

Hoëvell, G.W.W.C. baron van (1896). 'Bijschrift bij de kaarten van Seran (Vulgo Seran)', Tijdschrift van het Aardrijkskundig Genootschap 13:508-32.

Hugenholtz, W.R., (2008). Landrentebelasting op Java, 1812-1920. [PhD thesis, Leiden University, Leiden.]

Jensen, A.E. (1948). Die drei Ströme: Züge aus dem geistigen und religiösen Leben der Wemale: Einem Primitiv-Volk in den Molukken. Leipzig: Harrassowitz.

Kafka, B. (2007). 'The demon of writing: paperwork, public safety, and the reign of terror', Representations 98:1-24. 
Kloos, D. (2014). 'A crazy state: Violence, psychiatry, and colonialism in Aceh, Indonesia, c. 1910-1942', Bijdragen tot de Taal-, Land-en Volkenkunde 170-1:25-65.

Knaap, G. (1993). 'The Saniri Tiga Air (Seram). An account of its "discovery" and interpretation between about 1675 and 1950', Bijdragen tot de Taal-, Land- en Volkenkunde 149-2:250-73.

Li, T.M. (2007). The will to improve: Governmentality, development, and the practice of politics. Durham: Duke University Press.

Lindblad, J.Th. (1989). 'Economic aspects of the Dutch expansion in Indonesia, 18701914', Modern Asia Studies 23:1-24.

Locher-Scholten, E. (1981). Ethiek in fragmenten: Vijf studies over koloniaal denken en doen van Nederlanders in de Indonesische archipel, 1877-1942. Utrecht: Hes.

Locher-Scholten, E. (1994). 'Dutch expansion in the Indonesian archipelago around 1900 and the imperialism debate', Journal of Southeast Asia Studies 25-1:91-111.

Manuhutu, W. (1985). 'Pacificatie in praktijk: De expansie van het Nederlands gezag op Ceram, 1900-1942', in: J. van Goor (ed.), Imperialisme in de marge: De afronding van Nederlands-Indië, pp. 267-315. Utrecht: Hes.

Meijer Ranneft, J.W. and W. Huender (1926). Onderzoek naar den belastingdruk op de inlandsche bevolking. Weltevreden: 's Landsdrukkerij.

Noor, F.A. (2020). Data-gathering in colonial Southeast Asia 1800-1900: Framing the other. Amsterdam: Amsterdam University Press.

Ong Hok Ham (1975). The residency of Madiun: Priyayi and peasant in the nineteenth century. [PhD thesis, Yale University, New Haven.]

Raben, R. (2013). 'A new Dutch imperial history?: Perambulations in a prospective field', BMGN: Low Countries Historical Review 128-1:5-30.

Riedel, J.G.F. (1921). De sluik- en kroesharige rassen tusschen Selebes en Papua. 's Gravenhage: Nijhoff.

Ruinen, W. (1921). 'Sagopalmen en hunne beteekenis voor de Molukken', Indische Gids $43^{-1 / 2: 501-23,598-622 .}$

Ruinen, W. (1929). 'Ethnografische gegevens van West-Ceram', Mensch en Maatschappij 5:220-32.

Ruiter, T.G. (2002). 'State policy, peasantization and ethnicity: Changes in the Karo area of Langkat in colonial times', in: G. Benjamin and C. Chou (eds), Tribal communities in the Malay World: Historical, cultural and social perspectives, pp. 401-21. Singapore: ISEAS-Yusof Ishak Institute.

Rutten, L. (1920). 'Ontwikkelingsmogelijkheden van het eiland Ceram', Tijdschrift van het Aardrijkskundig Genootschap 27:43-73.

Sachse, F.J.P. (1907). Het eiland Seran en zijne bewoners. Leiden: Brill.

Sachse, F.J.P. (1919). Gegevens uit de nota betreffende de onderafdeeling West-Ceram. Batavia: Encyclopaedisch Bureau.

Sachse, F.J.P. (1922). Seran. Weltevreden: Kolff. 
Scott, D. (1995). 'Colonial governmentality', Social Text 43:191-220.

Scott, J.C. (1998). Seeing like a state: How certain schemes to improve the human condition have failed. New Haven: Yale University Press.

Scott, J.C. (2009). The art of not being governed: An anarchist history of upland Southeast Asia. New Haven: Yale University Press.

Slater, D. and D. Kim (2015). Standoffish states: Nonliterate Leviathans in Southeast Asia. TRaNS: Trans-Regional and-National Studies of Southeast Asia 3-1:25-44.

Stoler, A. (2009). Along the archival grain: Epistemic anxieties and colonial common sense. Princeton: Princeton University Press.

Szreter, S. and K. Breckenridge (2012). 'Editors' introduction. Recognition and registration: The infrastructure of personhood in world history', in: K. Breckenridge and S. Szreter (eds), Registration and recognition: Documenting the person in world history, pp. 1-38. Oxford: Oxford University Press.

Tauern, O.D. (1918). Patasiwa und Patalima: Vom Molukkeneiland Seran und seinen Bewohnern. Ein Beitrag zur Völkerkunde. Leipzig: Voigtländer.

Tichelman, G.L. (1925). 'De onder-afdeling Amahei (Seran)', Tijdschrift van het Aardrijkskundig Genootschap 42:653-724.

Vries, G. de (1927). Bij de Berg-Alfoeren op West-Seran: Zeden, gewoonten en mythologie van een oervolk. Zutphen: Thieme.

Wahid, A. (2013). From revenue farming to state monopoly: The political economy of taxation in colonial Indonesia, Java c. 1816-1942. [PhD thesis, Utrecht University, Utrecht.] 